УДК 611.16+611.835]:612.06-053.15

DOI: $10.24061 / 1727-0847.19 .4 .2020 .46$

\title{
T.B. Хмара
}

Кафедра анатомії людини імені М.Г. Туркевича (зав. - проф. В.В. Кривецький)

Буковинського державного медичного університету, м. Чернівиі

\section{ФЕТАЛЬНА АНАТОМІЯ СТРУКТУР СІДНИЧНОЇ ДІЛЯНКИ У ПЛОДІВ ЛЮДИНИ}

Резюме. У науковій літературі трапляються повідомлення, присвячені компресії нервів крижового сплетення ділянки таза або вище сідничної складки в різні вікові періоди життя людини. Проте, недостатньо уваги приділяється морфологами варіантам виходу соромітного, верхнього і нижнього сідничних судинно-нервових пучків та сідничого нерва з порожнини таза в перинатальному періоді онтогенезу людини. Для виконання лікувально-діагностичних маніпуляцій, а також оперативних втручань у сідничній ділянці необхідні точні відомості щодо проекційно-синтопічних взаємовідношень соромітного, верхнього і нижнього сідничних судинно-нервових пучків, і сідничого нерва у плодів людини різних вікових груп. Дослідження проведено на 34 препаратах плодів людини 186,0-310,0 мм тім'янокуприкової довжини. Матеріал фіксували в 7\% розчині формаліну впродовж двох тижнів, після чого методом тонкого препарування під контролем бінокулярної лупи ви-вчали топографоанатомічні особливості м'язів, судин і нервів сідничної ділянки в плодів 6-8 місяців. Препарати плодів людини отримували після операцій штучного переривання вагітності, які проводилися за соціальними і медичними показаннями на базі районних та міських пологових будинків. У 63,24\% досліджених плодів 6-8 місяців проекція верхніх сідничних судин відповідає точці, що знаходиться на межі між верхньою і середньою третинами остьово-вертлюгової лінії, рідше (33,82\% спостережень) - донизу (на 1,5-4,3 мм) і медіально (на 2,0-4,5 мм) від вказаної точки, і як виняток (лише 3\%) - на 5,0-5,5 мм латерально від цієї точки. Верхній сідничний нерв знаходиться на 1,0-3,8 мм латеральніше від однойменних судин. У 75,01\% випадків нижні сідничні судини виходять із таза медіально (на 2,0-4,7 мм) і донизу (на 1,5-4,2 мм) від середини остьово-горбової лінії. У 17,64\% спостережень проекція нижніх сідничних судин відповідає середині остьово-горбової лінії та у 7,35\% плодів проекція цих судин визначається на 2,5-3,4 мм назовні від точки, яка знаходиться посередині остьово-горбової лінії. Сідничий нерв виходить із таза переважно (75\% спостережень) медіально (на 2,0-5,4 мм) від середини горбово-вертлюгової лінії, а в 25\% випадках проекція сідничого нерва відповідає середині цієї лінії.

Ключові слова: сіднична ділянка, проекційні лінії, анатомія, плід, людина.

У теперішній час відомо безліч варіантів компресійних невропатій. При цьому, в ділянціі компресії відповідного нерва крижового сплетення, нерідко знаходять больові ущільнення чи потовщення тканин, що призводять до суттєвого звуження кістково-зв'язково-м'язових піхв, через які проходять нервово-судинні стовбури. Синдром грушоподібного м'яза виявляється не менш, ніж у 50\% хворих на дискогенний попереково-крижовий радикуліт. При цьому синдромі можливо стиснення сідничого нерва між зміненим грушоподібним м'язом і крижово-остьовою зв'язкою, або компресія сідничого нерва грушоподібним м'язом при проходженні нерва через м'яз - варіант розвитку сідничого нерва [1]. У науковій літературі трапляються повідомлення, присвячені компресії нервів крижового сплетення ділянки таза або вище сідничної складки в різні вікові періоди життя людини [2-4]. Проте, недостатньо уваги приділяється морфологами варіантам виходу соромітного, верхнього і нижнього сідничних судиннонервових пучків та сідничого нерва 3 порожнини таза в перинатальному періоді онтогенезу людини. Для виконання лікувально-діагностичних маніпуляцій, а також оперативних втручань у сідничній ділянці необхідні точні відомості щодо проекційно-синтопічних взаємовідношень соромітного, верхнього і нижнього сідничних судинно-нервових пучків, і сідничого нерва у плодів людини різних вікових груп.

Мета дослідження: з'ясувати взаємовідношення верхнього та нижнього сідничних су-

(C) T.B. Хмара, 2020 
динно-нервових пучків і сідничого нерва до проекційних ліній у плодів людини 6-8 місяців.

Матеріал і методи. Дослідження проведено на 34 препаратах плодів людини 186,0-310,0 мм тім'яно-куприкової довжсини (ТКД). Матеріал фік-сували в 7\% розчині формаліну впродовж двох тиж-нів, після чого методом тонкого препарування під контролем бінокулярної лупи вивчали топографоанатомічні особливості м'язів, судин і нервів сідничної ділянки в плодів 6-8 місяиів. Препарати плодів людини отримували після операцій штучного переривання вагітності, які проводилися за сочіальними і медичними показаннями на базі районних та міських пологових будинків Чернівецької області. Вивчали тільки ті випадки, коли причина смерті не була пов'язана з патологією органів порожнини таза, м'язів поясу нижньої кінцівки і судинно-нервових структур сідничної ділянки. Окрім изого, для дослідження типової $і$ варіантної анатомії верхнього $і$ нижнього сідничних судинно-нервових пучків і сідничого нерва використані препарати плодів людини з колекиії музею кафедри анатомії людини імені М.Г. Туркевича Буковинського державного медичного університету. Використані методи препарування, макромікроскопії, морфометрії, графічної зарисовки топографії судин і нервів, які виходять з таза через над- $і$ підгрушоподібний отвори та їх відношення до проекційний ліній сідничної ділянки. Послідовність препарування м'язів, фасціально-клітковинних просторів і судинно-нервових утворень сідничної ділянки в плодів людини здійснювали за методикою, яка запропонована нами [5].

Результати досліджень та їх обговорення. При визначенні топографії судин і нервів сідничної ділянки використовують проекційні лінії, вказівки на які в доступній нам літературі недостатньо точні. У постнатальному періоді онтогенезу людини при вивченні місць виходу з таза в сідничну ділянку судин і нервів, як правило, використовують три проекційні лінії: остьово-горбову, остьово-вертлюгову та горбово-вертлюгову (рис. 1).

Кістковими орієнтирами для проведення цих проекційних ліній є: верхня задня клубова ость, сідничий горб і великий вертлюг. Слід підкреслити, що сідничий горб кульшової кістки і великий вертлюг стегнової кістки знаходяться не на одному горизонтальному рівні - великий вертлюг розміщений дещо вище. Також необхідно відзначити те, що відношення сідничних судинно-нервових пучків і сідничого нерва до різних ліній таза залежить від того, які точки сідничого горба і ве-

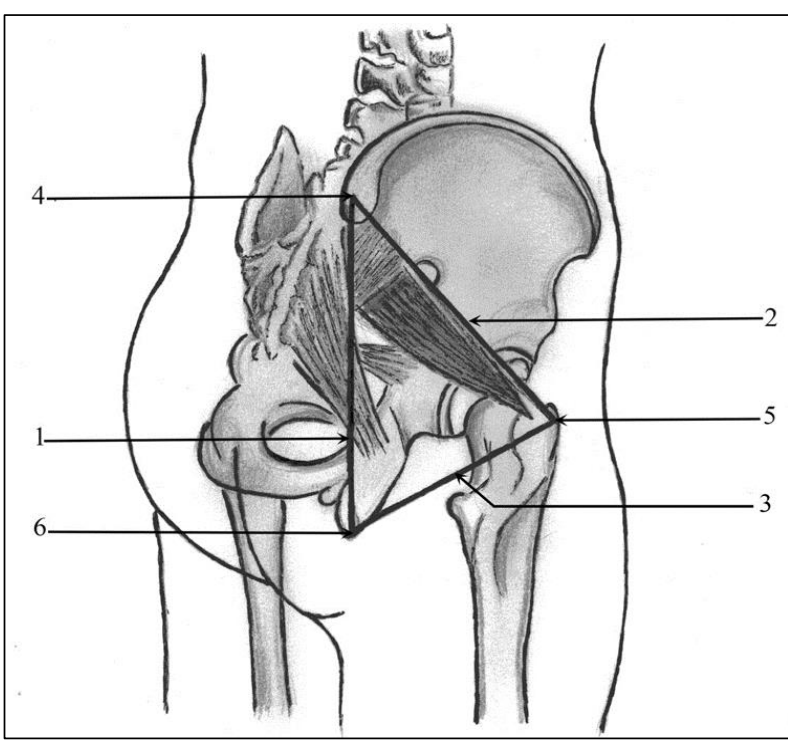

Рис. 1. Схема проекційних ліній правої сідничної ділянки (задньобічний вигляд): 1 - остьово-горбова лінія; 2 -остьово-вертлюгова лінія; 3 - горбово-вертлюгова лінія; 4 - верхня задня клубова ость; 5 - великий вертлюг; 6 - сідничий горб

ликого вертлюга з'єднуються між собою і з верхньою задньою клубовою остю. При цьому в літературі немає загальної думки щодо визначальних точок вищевказаних кісткових структур.

Остьово-горбову лінію (linea spinotuberalis) проводять від верхньої задньої клубової ості до бічного краю основи сідничого горба. Довжина цієї лінії у плодів 6 місяців становить 40,0-44,0 мм, у 7-місячних плодів - 44,5-50,0 мм, у плодів 8 місяців - 47,0-51,5 мм.

Остьово-вертлюгова лінія (linea spinotrochanterica) прямує від верхньої задньої клубової ості до верхівки, або бічного краю основи великого вертлюга. Висота великого вертлюга у досліджених плодів коливається від 9,0 мм до 14,8 мм. Слід зауважити, що мова йде про вер-хівку великого вертлюга в тому випадку, якщо він має трикутну або конусоподібну форму. У більшості (23) плодів верхівка великого вертлюга як правої, так і лівої стегнової кістки не загострена, а сплощена або заокруглена, і тоді великому вертлюгу притаманна інша форма - овальна, прямокутна, усіченого конуса чи піраміди. Необхідно відмітити, що у плодів людини у великому вертлюзі, слід виділяти таку частину як ос-нову. Довжина остьово-вертлюгової лінії у плодів 6 місяців дорівнює 32,037,0 мм, у плодів 7 місяців - 37,5-45,0 мм і у 8місячних плодів - 39,5-47,0 мм. Горбово-вертлюгова лінія (linea tuberotrochanterica) з'єднує нижньоприсередній край сідничого горба 3 бічним краєм основи великого вертлюга. Довжина цієї лінії у плодів 6 місяців становить 20,0-23,0 мм, у 7- 
місячних плодів - 23,5-26,0 мм, у плодів 8 місяців $-25,0-27,5$ мм.

Місце виходу верхнього сідничного судиннонервового пучка 3 надгрушоподібного отвору в деяких (9) випадках прикрито верхнім краєм грушо-подібного м'яза, а в окремих (5) спостереженнях - нижнім краєм середнього сідничного м'яза або відповідає проміжку між ними. Верхня сіднична артерія, як правило, виходить із надгрушоподібного отвору в точці, що знаходиться на межі між верхньою і середньою третинами остьово-вертлюгової лінії. У 8 досліджених плодів місце виходу правої верхньої сідничної артерії визначалось донизу (на 1,5-3,5 мм) і медіальніше (на 2,0-4,0 мм) від вказаної точки, і лише в двох випадках ( плоди 195,0 і 305,0 мм ТКД) права верхня сіднична артерія виходить із таза на 5,0-5,5 мм латеральніше цієї точки. У 15 плодів 6-8 місяців проекція лівої верхньої сідничної артерії визначалася донизу (на 2,5-4,3 мм) і медіальніше (на 3,04,5 мм) від точки, що знаходиться на межі між верхньою і середньою третинами остьово-вертлюгової лінії. Латеральніше (на 1,0-3,8 мм) від верхньої сідничної артерії знаходиться верхній сідничний нерв, гілки якого розгалужуться в проміжку між середнім і малим сідничними м'язами. Верхні сідничні вени при проходженні через щілину над грушоподібним м'язом (надгрушоподібний отвір) утворюють навколо м'яза венозне сплетення. Нижня сіднична артерія виходить із таза через підгрушоподібний отвір у супроводі одноіменних нерва і вени, розташовується медіальніше сідничого нерва на задній поверхні внутрішнього затульного, близнюкових м'язів, квадратного м'яза стегна, і прикрита великим сідничним м'язом (рис. 2) . Гілки нижнього сідничного не- рва, зазвичай, розташовуються на поверхні сідничого нерва. Слід відмітити, що тільки у 5 плодів проекція правої нижньої сідничної артерії і у 7 плодів проекція лівої нижньої сідничної артерії відповідали середині остьово-горбової лінії. У переважної більшості плодів як права, так і ліва нижня сіднична артерія виходила 3 таза дещо медіально (на 2,0-4,7 мм) і донизу (на 1,5-4,2 мм) від цієї точки. У трьох спостереженнях (плоди 205,0, 260,0 і 290,0 мм ТКД) права нижня сіднична артерія та у двох плодів 190,0 і 230,0 мм ТКД ліва нижня сіднична артерія розташовувались назовні (на 2,5-3,4 мм) від точки, яка знаходиться посередині остьово-горбової лінії. Від нижньої сідничної артерії відходить супутня артерія сідничого нерва, яка супроводжує цей нерв у його верхній третині та розташовується в товщі або на поверхні нерва.

Місце виходу сідничого нерва із таза, переважно знаходиться медіальніше (на 2,0-5,4 мм) від

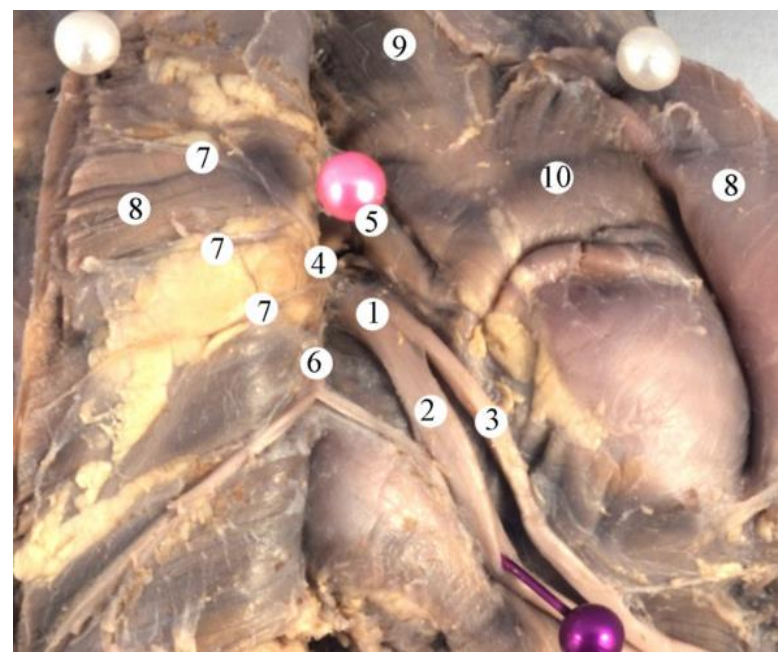

Рис. 2. Права сіднична ділянка плода 290,0 мм ТКД. Макропрепарат. 3б. 2,2x: 1 -сідничий нерв; 2 - великогомілковий нерв; 3 - загальний малогомілковий нерв; 4 - підгрушоподібний отвір; 5 - грушоподібний м'яз; 6-нижній сідничний нерв; 7 - нижні сідничні судини; 8-великий сідничний м'яз; 9 - середній сідничний м'яз; 10 - малий сідничний м'яз

середини горбово-вертлюгової лінії, а в 9 випадках проекція правого і у 8 спостереженнях лівого сідничих нервів відповідала середині цієї лінії. У досліджених плодів 6-8 місяців сідничий нерв на протязі від грушоподібного м'яза до сідничної складки проходить паралельно до остьово-горбової лінії, дещо назовні (на 2,5-6,3 мм) від неї.

Висновки. 1. У 63,24\% досліджених плодів 68 місяців проекція верхніх сідничних судин відповідає точці, що знаходиться на межі між верхньою і середньою третинами остьово-вертлюгової лінії, piдше (33,82\% спостережень) - донизу (на 1,5-4,3 мм) і медіально (на 2,0-4,5 мм) від вказаної точки, і як виняток (лише 3\%) - на 5,0-5,5 мм латерально від цієї точки. Верхній сідничний нерв знаходиться на 1,0-3,8 мм латеральніше від однойменних судин. 2. У 75,01\% випадків нижні сідничні судини виходять із таза медіально (на 2,0-4,7 мм) і донизу (на 1,5-4,2 мм) від середини остьово-горбової лінії. У 17,64\% спостережень проекція нижніх сідничних судин відповідає середині остьово-горбової лінії та у 7,35\% плодів проекція цих судин визначається на 2,5-3,4 мм назовні від точки, яка знаходиться посередині остьово-горбової лінії. 3. Сідничий нерв виходить із таза переважно (75\% спостережень) медіально (на 2,0-5,4 мм) від середини горбово-вертлюгової лінії, а в $25 \%$ випадках проекція сідничого нерва відповідає середині цієї лінії.

Перспективи подальших досліджень. 3'ясування проекційно-синтопічних взаємовідношень верхнього і нижнього сідничних та соромітного судинно-нервових пучків наприкінці плодового періоду онтогенезу людини. 


\section{Список використаної літератури}

1. Путилина МВ. Невропатия седалищного нерва. Синдром грушевидной мышщы. Лечащий врач. 2006;(2):54-8.

2. Бабоша ВА, Лобанов ГВ, Шимченко ВА. и др. Удаление опухоли седалищного нерва с интра- экстратазовым расположением. Ортопед., травматолог. и протезирование. 2009;(2):104-5.

3. Орлов АЮ, Кокин ГС, Короткевич ММ. Оптимальные доступы при удалении опухолей поясничнокрестиового сплетения и его ветвей на разных уровнях. Нейрохирургия и неврология детского возpacma. 2012;31(1):49-52.

4. Antolak SJJ, Hough DM, Pawlina W, et al. Anatomical basis of chronic pelvic pain syndrome: the ischial spine and pudendal nerve entrapment. Med. Hypotheses. 2002;59:349-53.

5. Хмара ТВ, Васильчишина АВ, Лойтра АО. та ін. Особливості анатомічного препарування м'язів, фасиіально-клітковинних просторів і судинно-нервових утворень сідничної ділянки у плодів людини. Укр. мед. альманах. 2013;16(1):105-8.

\section{References}

1. Putilina MV. Nevropatiya sedalishchnogo nerva. Sindrom grushevidnoy myshtsy. Lechashchiy vrach. 2006;(2):54-8. (in Russian)

2. Babosha VA, Lobanov GV, Shimchenko VA. i dr. Udaleniye opukholi sedalishchnogo nerva s intra- ekstratazovym raspolozheniyem. Ortoped., travmatolog. i protezirovaniye. 2009;(2):104-5. (in Russian)

3. Orlov AYU, Kokin GS, Korotkevich MM. Optimal'nyye dostupy pri udalenii opukholey poyas-nichnokresttsovogo spleteniya i yego vetvey na raznykh urovnyakh. Neyrokhirurgiya i nevrologiya detskogo vozrasta. 2012;31(1):49-52. (in Russiam)

4. Antolak SJJ, Hough DM, Pawlina W, et al. Anatomical basis of chronic pelvic pain syndrome: the ischial spine and pudendal nerve entrapment. Med. Hypotheses. 2002;59:349-53.

5. Khmara TV, Vasil'chishina AV, Loytra AO. ta in. Osoblivostí anatomíchnogo preparuvannya m'yaziv, fastsial'no-klitkovinnikh prostoriv i sudinno-nervovikh utvoren' sídnichnö̈ dilyanki u plodiv lyudini. Ukr. med. al'manakh. 2013;16(1):105-8.

\section{ФЕТАЛЬНАЯ АНАТОМИЯ СТРУКТУР ЯГОДИЧНОЙ ОБЛАСТИ У ПЛОДА ЧЕЛОВЕКА}

Резюме. В научной литературе встречаются сообщения, посвященные компрессии нервов крестцового сплетения участка таза или выше ягодичной складки в разные возрастные периоды жизни человека. Однако, недостаточно внимания уделяется морфологами вариантам выхода срамного, верхнего и нижнего ягодичных сосудисто-нервных пучков и седалищного нерва из полости таза в перинатальном периоде онтогенеза человека. Для выполнения лечебно-диагностических манипуляций, а также оперативных вмешательств в ягодичной области необходимы точные сведения о проекционно-синтопических взаимоотношений срамного, верхнего и нижнего ягодичных сосудисто-нервных пучков и седалищного нерва у плодов человека разных возрастных групп. Исследование проведено на 34 препаратах плодов человека 186,0-310,0 мм теменно-копчиковой длины. Материал фиксировали в $7 \%$ растворе формалина в течение двух недель, после чего методом тонкого препарирования под контролем бинокулярной лупы изучали топографоанатомические особенности мышц, сосудов и нервов ягодичной области у плодов 6-8 месяцев. Препараты плодов человека получали после операций искусственного прерывания беременности, которые проводились по социальным и медицинским показаниям на базе районных и городских роддомов. В $63,24 \%$ исследованных плодов 6-8 месяцев проекция верхних ягодичных сосудов соответствует точке, находящейся на границе между верхней и средней третей остевовертлужной линии, реже (33,82\% наблюдений) - вниз (на 1,5-4, 3 мм) и медиально (на 2,0-4,5 мм) от указанной точки, и как исключение (всего 3\%) - на 5,0-5,5 мм латерально от этой точки. Верхний седалищный нерв находится на 1,0-3,8 мм латеральнее от одноименных сосудов. В 75,01\% случаев нижние ягодичные сосуды выходят из таза медиально (на 2,0-4,7 мм) и вниз (на 1,5-4,2 мм) от середины остево-горбовой линии. В 17,64\% наблюдений проекция нижних ягодичных сосудов соответствует середине остево-горбовой линии и в 7,35\% плодов проекция этих сосудов определяется на 2,5-3,4 мм кнаружи от точки, которая находится посередине остево-горбовой линии. Седалищный нерв выходит из таза преимущественно (75\% наблюдений) медиально (на 2,0-5,4 мм) от середины горбово-вертлужной линии, а в $25 \%$ случаях проекция седалищного нерва соответствует середине этой линии.

Ключевые слова: ягодичная область, проекционные линии, анатомия, плод, человек. 
FETAL ANATOMY OF THE STRUCTURES OF THE BUTTLE REGION IN THE HUMAN FETUS Abstract. In the scientific literature, there are reports on the compression of the nerves of the sacral plexus of the pelvic area or above the gluteal fold in different age periods of a person's life. However, not enough attention is paid by morphologists to the options for the exit of the pudendal, superior and inferior gluteal neurovascular bundles and the sciatic nerve from the pelvic cavity in the perinatal period of human ontogenesis. To perform therapeutic and diagnostic manipulations, as well as surgical interventions in the gluteal region, accurate information is required about the projection-syntopic relationships of the pudendal, superior and lower gluteal neurovascular bundles and the sciatic nerve in human fetuses of different age groups. The study was carried out on 34 preparations of human fetuses, 186.0-310.0 $\mathrm{mm}$ parietococcygeal length. The material was fixed in a 7\% formalin solution for two weeks, after which the topographic anatomical features of the muscles, blood vessels and nerves of the gluteal region in fetuses of 6-8 months were studied by fine dissection under the control of a binocular loupe. Human fetal preparations were received after artificial termination of pregnancy, which were carried out for social and medical reasons on the basis of district and city maternity hospitals. In $63.24 \%$ of the examined fetuses of 6-8 months, the projection of the superior gluteal vessels corresponds to the point located on the border between the upper and middle third osteocetabular line, less often (33.82\% of observations) - downward (by $1.5-4,3 \mathrm{~mm}$ ) and medially $(2.0-4.5 \mathrm{~mm}$ ) from the specified point, and as an exception (only $3 \%$ ) - 5.0-5.5 mm laterally from this point. The superior sciatic nerve is located 1.0$3.8 \mathrm{~mm}$ lateral to the vessels of the same name. In $75.01 \%$ of cases, the lower gluteal vessels leave the pelvis medially (by $2.0-4.7 \mathrm{~mm}$ ) and down (by 1.5-4.2 mm) from the middle of the osteo-hump line. In $17.64 \%$ of observations, the projection of the lower gluteal vessels corresponds to the middle of the osteo-hump line, and in 7.35\% of the fetuses, the projection of these vessels is determined 2.5-3.4 mm outward from the point located in the middle of the osteo-hump line. The sciatic nerve leaves the pelvis mainly ( $75 \%$ of observations) medially (2.0-5.4 mm) from the middle of the hump-acetabular line, and in $25 \%$ of cases the projection of the sciatic nerve corresponds to the middle of this line.

Key words: gluteal area, projectors, anatomy, fetus, human.

Відомості про автора:

Хмара Тетяна Володимирівна - д-р. мед. наук., професор, професор кафедри анатомії людини імені М.Г. Туркевича Буковинського державного медичного університету, м. Чернівці.

Information about author:

Khmara Tetiana Volodymyrivna - Doctor of Medical Sciences, Professor, Professor of the M.H. Turkevych Human Anatomy Department of Bukovinian State Medical University, Chernivtsi.

Надійшла 19.05.2020 p. Рецензент - проф. Слободян О.М. (Чернівці) 